\title{
Educational Tracks Of Russian Youth In System Of Education (On State Statistics 2000-2017)
}

\author{
Cherednichenko Galina \\ Doctor of Sciences (Sociology), \\ Institute of Sociology of the Federal Center of Theoretical and \\ Applied Sociology of the Russian Academy of Sciences (FCTAS RAS)
}

\begin{abstract}
ANNOTATION
Unlike in developed countries, there are few indicators in the Russian education statistics concerning youth educational tracks between its successive levels, from the basic to the higher one. Since 2014, the Ministry of Education and Science of Russia has published raw statistical data, inaccessible to readers as they are, on its website. The author has calculated and analyzed a number of relevant indicators from this and other sources. The evaluation is focused on the 2000-2017 changes in the enrollment in Basic and Secondary Schools and subsequent distribution of students across educational tracks; enrollment in Secondary Vocational Education (mid-level specialist and skilled worker programs), distribution of students across modes of study and educational attainment at admission; enrollment in Higher Education Institutions across modes of study, types of Higher Education Institutions ownership and educational attainment at admission to full-time and extramural classes. The data on the number of relevant age cohorts inform the analysis.
\end{abstract}

Keywords: Basic, Secondary, Vocational, Higher Education in Russia; educational tracks.

\section{INTRODUCTION}

Different countries and regions vary in their strategies of developing education and training systems and offering youth a wide range of post-school studies, from skilled-worker programs to university education. Youth distribution across education and vocational training levels and educational tracks between them vary as well. The peculiarities of a country's education system have a considerable effect on its possibilities for socioeconomic and technological transformations, being one of the main instruments for increasing its competitiveness in general and that of each person in particular. Even an initial evaluation of the correlation between population coverage with different educational levels and structure of economies shows that, along with the economic effects, education impacts primary social and cultural mechanisms of formation of key contemporary public institutions.

The statistical data on the educational tracks of young people between educational levels and modes of study inform basic and applied research concerning, in particular, their subdivision into those pursuing their studies at different levels, dropouts and labor market entrants. These data appear in ongoing discussions about the most important problems in Higher Education pertaining to its massovization, quality of education, differentiation of educational institutions, education policies, accessibility and inequality problems. Such information is used in discussions in Russia concerning the growing disparity between the actual demand in the labor market for a set of skills and their supply, which many tend to attribute to the disproportion between Higher and Secondary Vocational Education.

Statistical data on education in Russia are underrepresented in international publications. A competent OECD statistical publication contains only six indicators on the subject (Education at a Glance 2017: 248-258). Few of them are also present in the database The World Bank. 
Education Statistics. (The World Bank). The latest edition of the data book Education in the Russian Federation (Obrazovanie 2014) containing substantial information on education in Russia was published in 2014. Concise data books Indicators of Education (Indikatoryi 2018) and Education in Figures (Obrazovanie, 2018) contain few data on the development of particular educational levels. No information is available on the educational tracks of youth. The present article is an attempt at filling this information gap.

\section{METHODOLOGICAL EXPLANATIONS}

The author has made calculations based on raw statistical information posted since 2014 on the website of the Ministry of Education and Science of the Russian Federation (Ministerstvo) and primary statistics for 2000-2010 the Federal State Statistics Service has officially provided to the author as a member of the Department of Sociology of Education of the Institute of Sociology of the Russian Academy of Sciences (Primary). Statistical data on education in Russia collected by relevant corporate statistics may be used for extracting sociological meanings and implications and revealing sociological regularities, since such meanings and implications are implicitly contained in these data and determined by the social realities reflected in the quantitative assessments conveyed by the data. The analysis employs descriptive statistics methods permitting to group data sets, describe their characteristics, identify relationships between variables, in particular, when analyzing chronological changes, and represent them in diagrams and tables. The author uses the methodology presented in S. Boslaugh's publication (Boslaugh 2013).

For easier understanding of the following text and possibility of international comparisons, a description of levels of education in Russia conforming to the ISCED is presented below (Rossiyskaya 2016).

1. Basic General Education: 11/5, ISCED 244 (entrance age/duration, marches ISCED program three-digit code 100: $1^{\text {st }}$ figure - level, $2^{\text {nd }}-$ type of orientation, $3^{\text {rd }}-$ access subtype).

2. Secondary General Education: 16/2, ISCED 344.

3. Secondary Vocational Education - Skilled Worker Programs (SWP): 16-18/1-2,5, 454.

4. Secondary Vocational Education - Mid-Level Specialist Programs (MLSP): 16-18/1-4, 554.

5. Higher Education: 18/4, 665; 18/5-6, 766; 22/2, 767

Secondary General Education (Secondary School) is equivalent to High School; Higher Education system is represented by differently called Higher Education Institutions (HEIs): a university (for example, Lomonosov Moscow State University), an academy (Tver State Medical Academy), an institute (Voronezh State Institute of Arts) or a school (Moscow School of Social and Economic Sciences).

\section{Basic School}

\section{FINDINGS}

Basic General Education is practically universal in Russia. The proportion of Basic School graduates vs. enrollment in the first grade nine years before constituted $97.0 \%$ in 2000 and $97.3 \%$ in 2017. The functioning of all levels of the education system is under a considerable impact of the demographic factor - substantial periodic numerical fluctuations in the age cohorts of children, teenagers, and youth. These fluctuations echo plummeting birthrates during World War II and the subsequent baby boom. That demographic wave has been periodically reproduced to this day. 
The demographic factor has governed changes in the number of both urban and rural Basic School graduates (Figure 1). Graphs illustrating the number of graduates generally replicate those of the conventional 15-year-old cohort (due to lack of data on the 15-year-old population, their conventional cohort is based on the number of persons born 15 years before. Death rates at this age are low and insignificant for comparison purposes.15 years is the modal value in the age distribution of graduates). In periods of a sharp reduction in the teenage population (by $51.4 \%$ in 2002-2008), the number of urban graduates decreased less (by $42.3 \%$ ) and the decline in the number of rural graduates was even smaller (33.5\%). Having reached its minimum in 2014, the number of urban graduates experienced a slower increase than the relevant age cohort did (by 2017, 8.2\% and 15\% respectively) whereas the number of rural graduates decreased (by 3.8\%). This means that against the background of a falling demographic wave, when chances of all teenagers to complete Basic Schooling were increasing, rural teenagers were more likely to complete it than their urban counterparts were. At the same time, the number of both urban and rural Basic School graduates decreased when the number of peers was increasing.

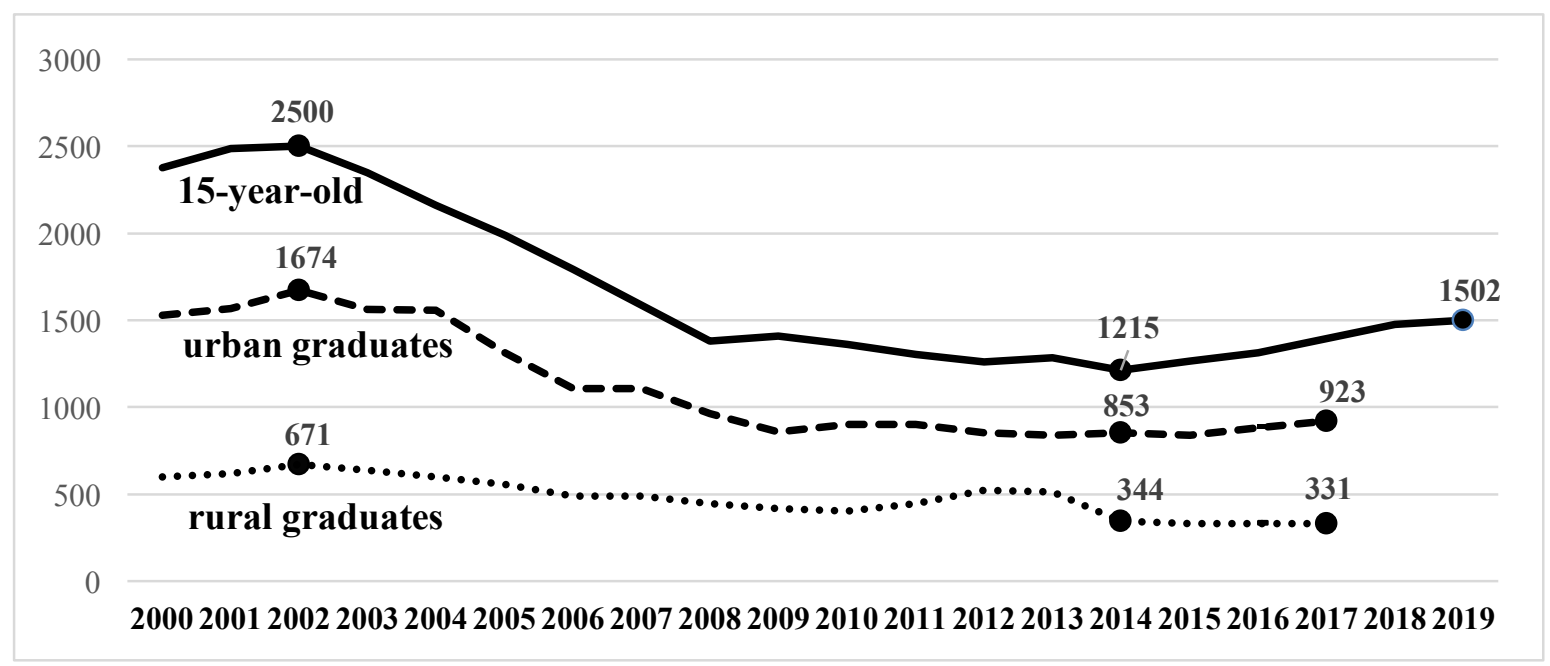

Figure 1. The size of the conventional 15-year-old cohort and the population of urban and rural Basic School graduates $(1,000)$

Additional sources: Goskomstat 2001, 133; Rosstat 2015, 37.

In Russia, the first choice of the educational path takes place after the Basic School graduation. There are three options: 1. Proceeding to Secondary School, with a majority of graduates entering HEIs; 2. Joining mid-level specialist programs (MLSP) of Secondary Vocational Education (SVE); and 3. Joining skilled worker programs (SWP) SVE. Students selecting the second and the third options may move after graduation to HEIs.

Due to a number of factors, the proportion of Basic School graduates proceeding to Secondary School was decreasing faster in rural than in urban areas (down by more than a third and $13 \%$ respectively). (Figure 2). The reducing number of rural Secondary Schools forced youth move to nearby towns for further education. More of them entered SVE, since their chances improved as the number of their peers decreased. In 2002-2014, the proportion of enrollees in the conventional 15-year-old cohort increased from $30.5 \%$ to $43.8 \%$. Later, the SWP enrollment decreased slightly but chances of young people to join SVE remain high $339.0 \%$ in 2017). 


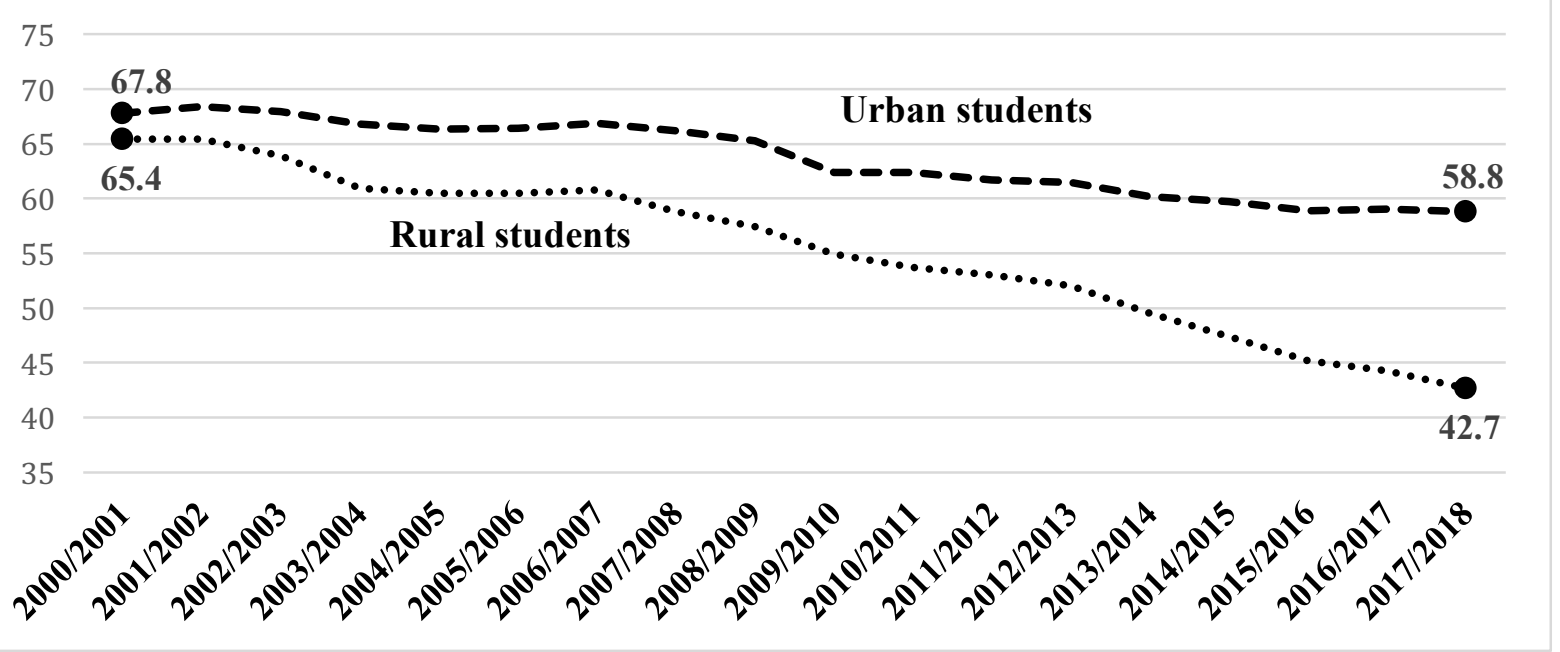

Figure 2. The proportion of Basic School graduates proceeding to Secondary School, \%

Additional sources: Obrazovanie 2014, 252

Figure 3 illustrates the dynamics of educational tracks of Basic School graduates. The smaller proportion of SWP enrollees is due to curtailed enrollment, which decreased especially sharply after 2008 (see more below). The main change was redistribution of students proceeding to Secondary School and MLSP due to institutional transformations. When graduating

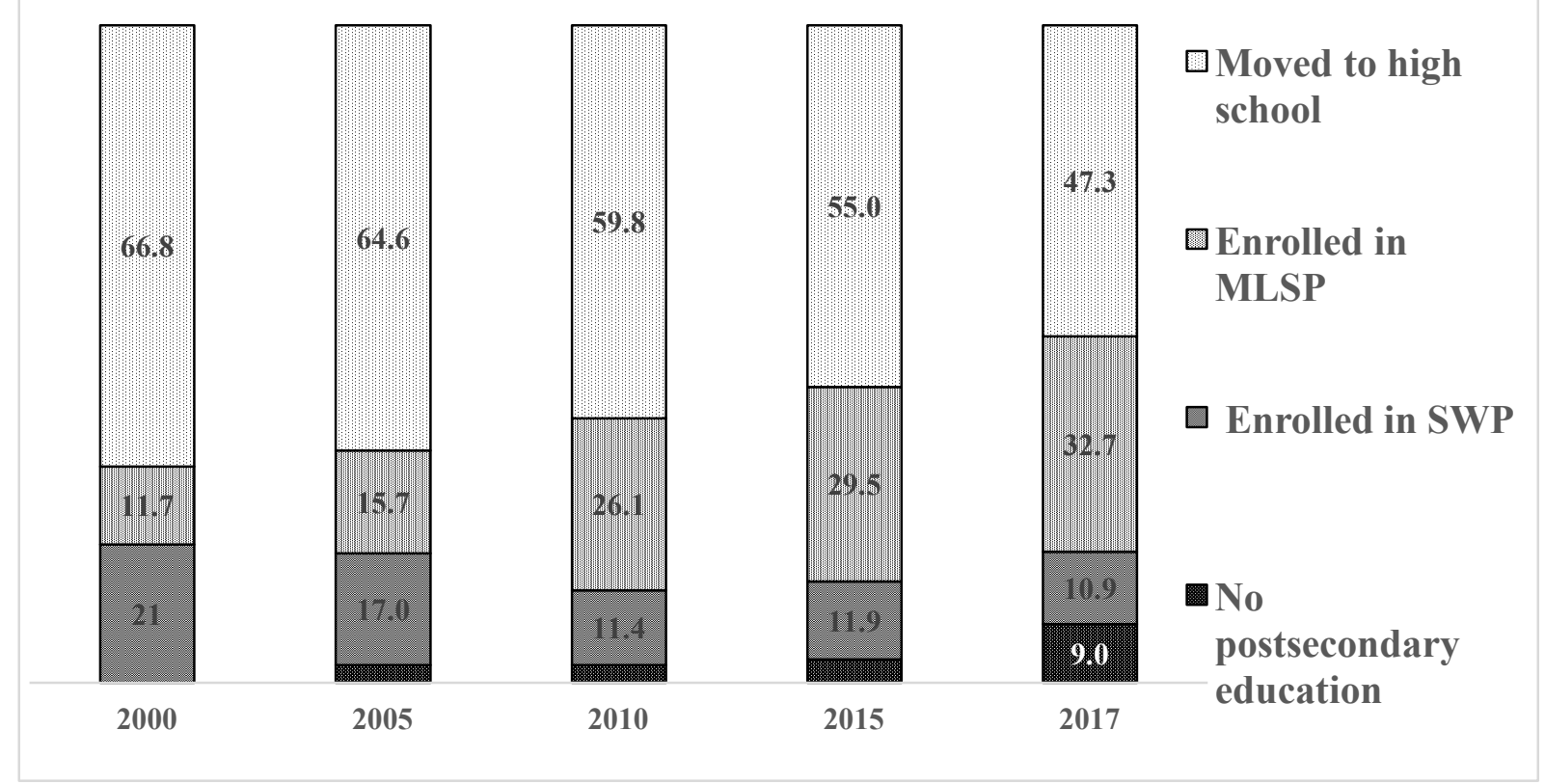

Figure 3. Distribution of Basic School graduates across educational tracks, \%

from Secondary School, students take a Unified State Exam (USE), which is simultaneously an entrance examination to HEIs. The exam was introduced in a number of regions in 2002, and since 2009, it has been held throughout the country. SVE graduates, along with a profession, obtain Secondary Education without having to take the USE and may enter HEIs on a competitive basis. An increasing number of students follow the path "Basic School to MLSP to HEI" as an option with the best benefit/cost ratio providing a mid-level specialist occupation in the labor market and an opportunity of entering a HEI without taking the USE. This alternative path, used by persons with limited educational and social resources, serves as a social mobility channel for youth occupying an intermediate position between those reproducing the skilled- 
worker status and the high-skilled professional status. According to the Monitoring of Education Markets and Organizations, in 2001-2014, an average of 31\% of MLSP graduates entered HEIs immediately upon graduation (Srednee 2016,1). This means that MLSP as an educational institution designated for the training of mid-level specialists loses much of its basic function and turns into a bypass transit to higher education. The pressure of this track partly stimulates the growth of that sector of higher education, which does not ensure its high quality.

\section{Secondary School}

The number of Secondary School graduates changes under the impact of annual variations in the conventional 17-year-old cohort (17 years is the modal value in the distribution of graduate students by age). (Figure 4). In 2004-2008, when the 17-year-old population decreased by $44.8 \%$, the number of rural school graduates dropped by an equivalent value of $44.6 \%$ against $49.9 \%$ of urban school graduates. In 2012-2017, a period of greater stability in the peer population when it decreased by as little as $7.1 \%$, the reduction in the number of graduates was very strong (33.9\%) in rural schools and substantial (11.3\%) in urban schools. Therefore, the USE introduction produced a different impact on urban and rural youth, preventing some of them from proceeding to Secondary School and thereby reducing the number of its graduates. Rural youth started using the "School to MLSP to University" track later than urban youth but did it more intensively.

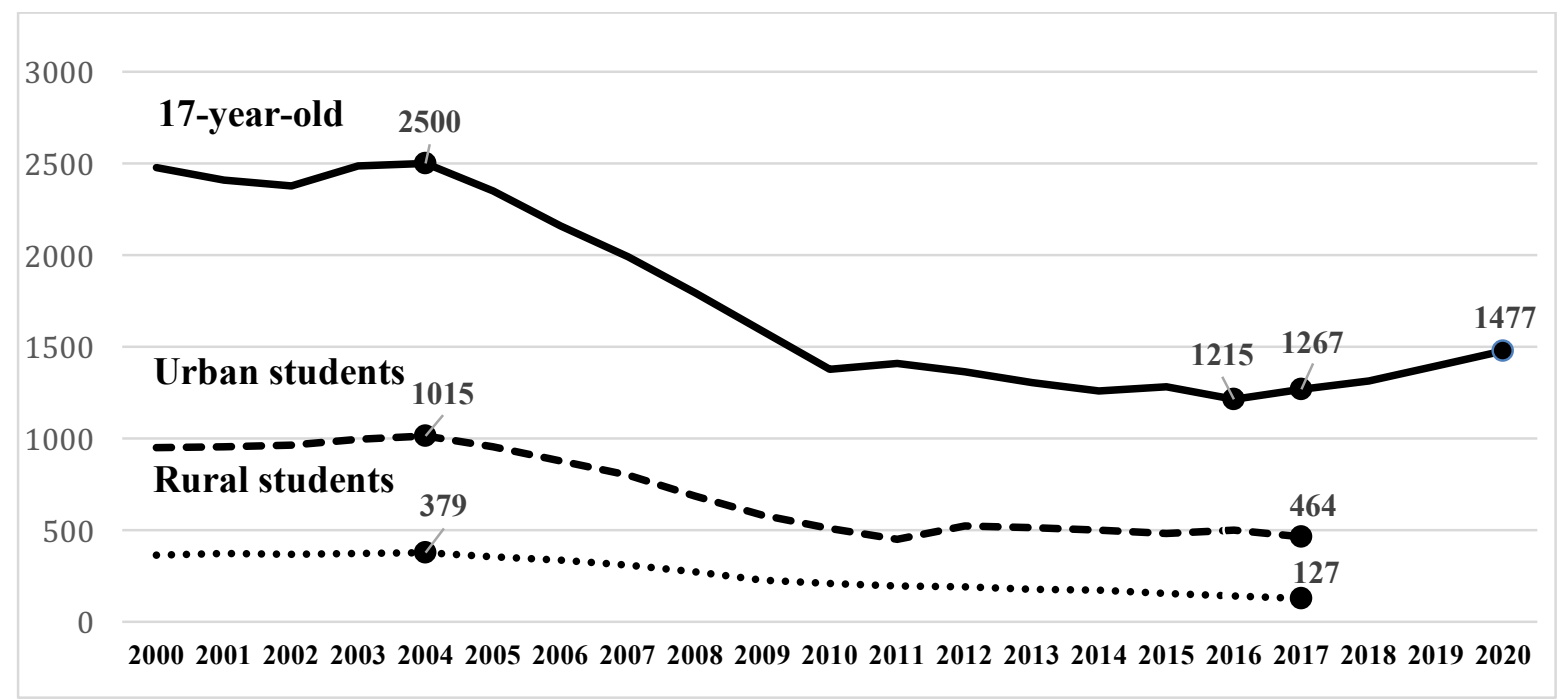

Figure 4. Size of the conventional 17-year-old cohort as compared to the population of urban and rural Secondary School graduates $(1,000)$

\section{Additional sources: Goskomstat 2001, 133; Rosstat 2015, 37}

Youth distribution across educational tracks upon graduation from Secondary School has changed considerably (Figure 5). Once again, graduates may enroll not only in HEIs but also in MLSP and SWP with a shorter tuition period. At the start of the period (Figure 2), when two thirds of youth procceded to Secondary School upon graduation from Basic School, most of them selected their further educational track after graduating from the former. At that time, a substantial proportion of Secondary School graduates enrolled in SVE and quite a few dropped out.

Subsequent years witnessed a redistribution of educational tracks following a rapid expansion of the Higher Education system and a sharp reduction in the relevant age cohort (especially in 
2004-2010). By 2010, the number of Secondary School graduates approached full-time HEI enrollment - 756,300 and 659,600 persons respectively. After the USE introduction, fewer students proceeded to Secondary School, mostly those with high educational outcomes. Therefore, its graduates were more competitive when entering HEIs. Current-year graduates constitute a majority of full-time enrollments at public HEIs (81\% in 2010 and 77\% in 2017). The proportion of Secondary School graduates entering HEIs was growing and today has become predominantly.

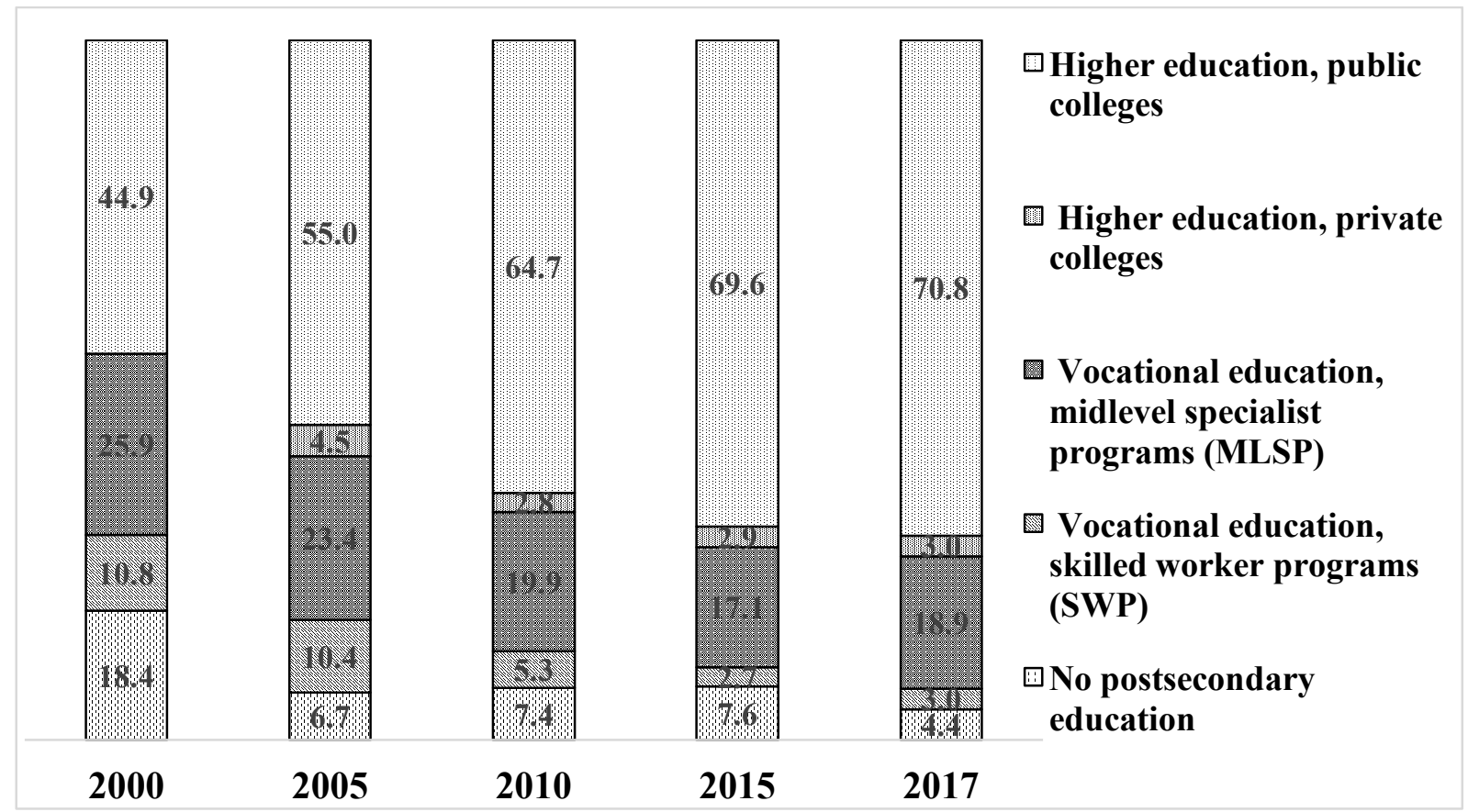

Figure 5. Distribution of Secondary School graduates across educational tracks, \%

Decreasing proportions of Secondary School graduates joining MLSP and SWP are partly a compensatory result of a broader use of the "School to HEI" track and partly a consequence of a more frequent choice of SVE upon graduation by those Secondary School graduates most of whom tried to enter HEIs but failed and decided to obtain lower-level skills. 
Figure 6 shows the distribution of students enrolled in the first grade of General School in
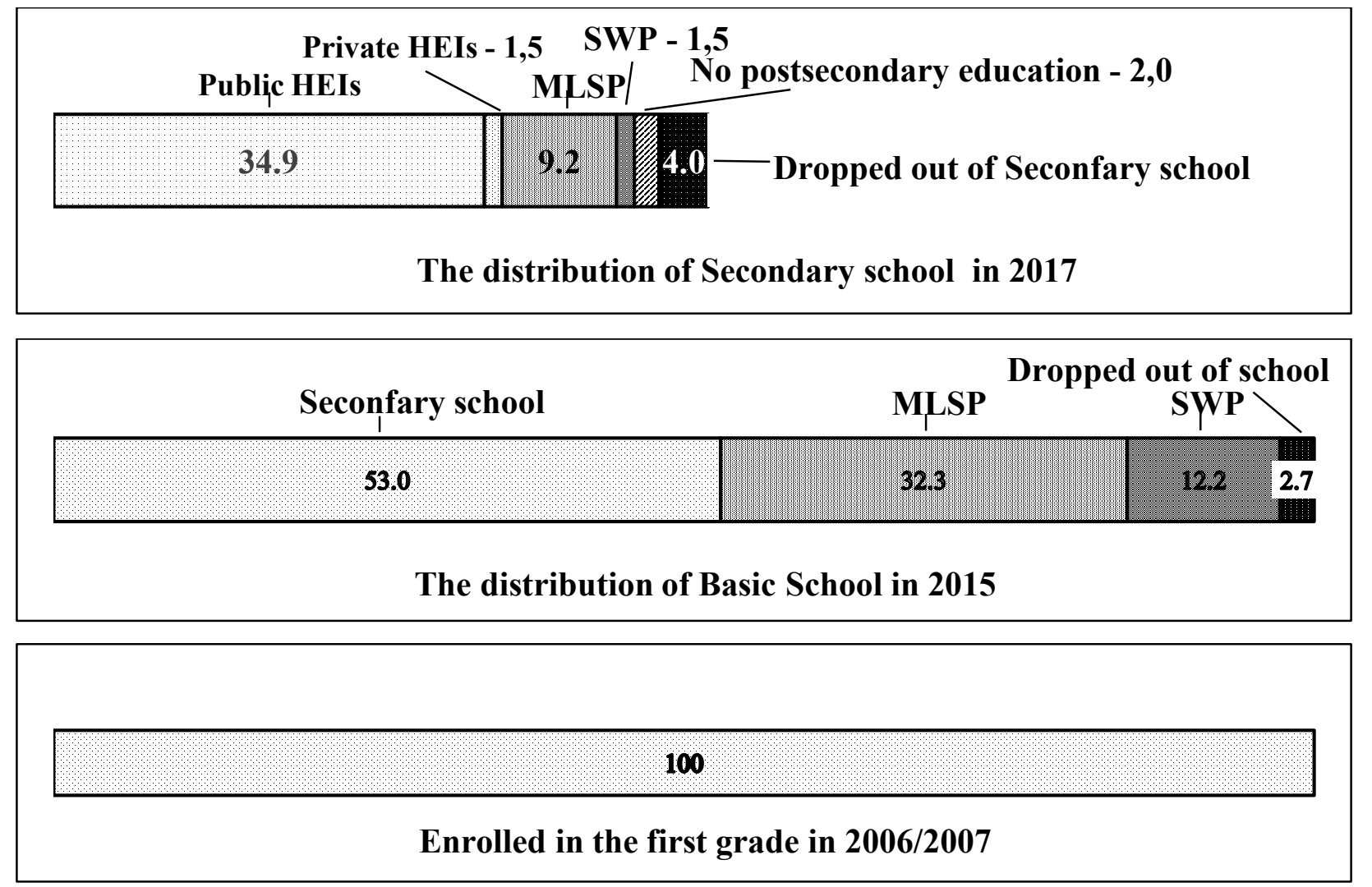

Figure 6. Distribution of Students Enrolled in the First Grade in 2006/07 after Graduation Basic School in 2015 and Secondary School in 2017

the academic year 2006/07 across further educational tracks: upon graduation from Basic School in 2015 (after nine years of study) and graduation from Secondary School in 2017 (after 11 years of study). The table illustrates proportions of educational tracks followed by peers at the point of choice during schooling. Practically, the entire youth cohort graduates from the compulsory Basic School, more than half of it goes to the Secondary School and about a third to MLSP; in the year of graduation from Secondary School, more than a third of the cohort enroll in Higher Education; just over half of the cohort misses secondary school The institutional possibilities offered by the Russian education system permit young people change and improve their initial educational status later.

\section{Secondary Vocational Education: Skilled Worker Programs (SWP)}

Until mid-1990s, SWP have offered youth sufficiently broad vocational training opportunities. Since then, they have been steadily reducing, primarily due to decreasing public investment. The trend has been accompanied by a decrease in youth populations thereby increasing their chances for entering HEIs and MLSP and reducing the number of SWP contenders. This is reflected in the SWP enrollment indicators that were falling faster over years: by $18.6 \%$ in $2000-2005$, by $38.2 \%$ in the subsequent five years and by $48.3 \%$ in the seven-year period from 2010 to 2017. In 2000-2017, total enrollment suffered a 3.8-fold reduction. The proportion of SWP students in the conventional 15-17-year-old cohort dropped from $11.6 \%$ in 2000 to 5.5\% in 2017.

SWP programs enroll both Basic and Secondary School graduates. In 2000-2017, Basic School graduates constituted the greater and ever increasing part of the SWP enrollment (Table 1), 
which correlates with the above-mentioned dynamics of Basic and Secondary School graduates' educational tracks (Fig. 3 and 5).

Table 1

Levels of education of students enrolled in Skilled Worker Programs of SVE, \%

\begin{tabular}{lccccc}
\hline & 2000 & 2005 & 2010 & 2015 & 2017 \\
\hline Basic school, interrupted & 5.0 & 4.9 & 6.8 & 8.4 & 0.2 \\
Basic school, graduation in the current year & 61.7 & 62.8 & 52.2 & 57.4 & 62.0 \\
Basic school, graduation in previous years & 5.6 & 8.4 & 16.8 & 20.3 & 18.4 \\
Secondary school, graduation in the current year & 21.2 & 18.0 & 9.1 & 5.5 & 8.0 \\
Secondary school, graduation in previous years & 6.5 & 5.8 & 15.1 & 8.5 & 10.5 \\
SVE, MLSP & - & - & - & - & 1.0 \\
Total & 100 & 100 & 100 & 100 & 100 \\
\hline
\end{tabular}

The proportion of enrolled current-year Basic School graduates remains, with slight variations, unchanged whereas the proportion of graduates who completed their Basic Schooling in previous years is substantially increasing. In 2000, the ratio of current-year and previous years' graduates was 10:1 whereas today it is 3:1. The proportion of Secondary School graduates enrolled in SWP is small and decreasing, while the number of previous years' graduates is increasing. Therefore, those who entered the labour market immediately after graduation from both Basic and Secondary School started to return to the education system for vocational training later.

\section{Secondary Vocational Education: Mid-Level Specialist Programs (MLSP)}

MLSP training has been steadily popular among youth from the grassroots. Competition for admission reached its maximum in 2003 (153 persons per 100 seats), dropped to its minimum in 2008 (131 per 100) and rose to 142 in 2017 (146 persons for state-funded and 138 persons for self-paying seats).

MLSP enrollment dynamics across modes of study is presented in Figure 7.

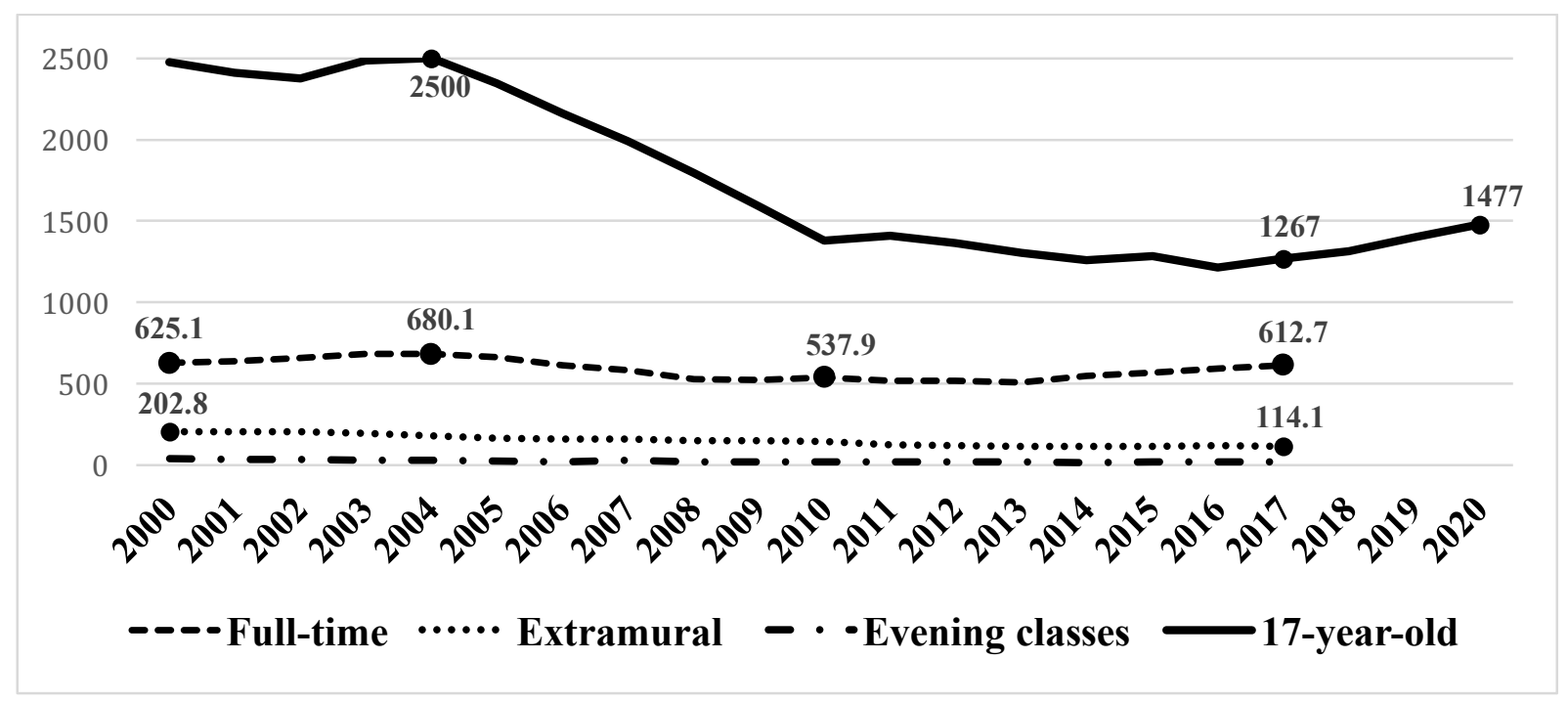

Figure 7. Enrollment in Mid-Level Specialist Programs across modes of study

Additional sources: Obrazovanie Additional sources :Obrazovanie 2014, 320. 
In 2000-2017, enrollment in less popular modes of study was decreasing: it dropped by less than half in the extramural and by more than half in the evening modes of study. Full-time enrollment was changing differently. In conditions of numerous 2000-2004 youth cohorts, it increased by 8.8\%; in 2004-2010, a period of a sharp decline in their numbers (by 44.8\%), its decrease was considerably smaller (by 20.9\%); and when youth population decreased insignificantly (by 8.1\% in 2010-2017), enrollment grew by13.9\%. Thus, the coverage of the age cohort by full-time MLSP was steadily increasing, especially in recent years, reflecting the above-mentioned trend towards using this training channel as an alternative path to higher education.

The enrollment structure across modes of study has remained rather stable throughout the reviewed period. Enrollment in full-time, extramural and evening studies constituted 72.1\%, $23.4 \%$ and $4.4 \%$ respectively in $2000 ; 76.3 \%, 20.0 \%$ and $2.7 \%$ in 2010 ; and $82.4 \%, 15,3 \%$ and $2.3 \%$ in 2017 . A certain increase in full-time enrollment (and a compensatory decrease in the other two) reflects students' preference of this more substantial mode of study.

In the reviewed period, nine out of ten entrants - and by 2017, even 95\% of them - were Basic and Secondary School graduates. Changes in the ratio between the two groups of entrants characterize MLSP enrollment dynamics (Figure 8). In 2008, the earlier predominance of Secondary School graduates over Basic School graduates was replaced by equal representation of both groups and was followed by the increasing prevalence of Basic School graduates later. Such dynamics correlates with the above-mentioned changes, namely, the decreasing proportion of Basic School graduates proceeding to Secondary School, especially in rural areas (Fig. 2), and the increasing proportion of MLSP enrollment upon graduation from Basic School (Fig. 3).

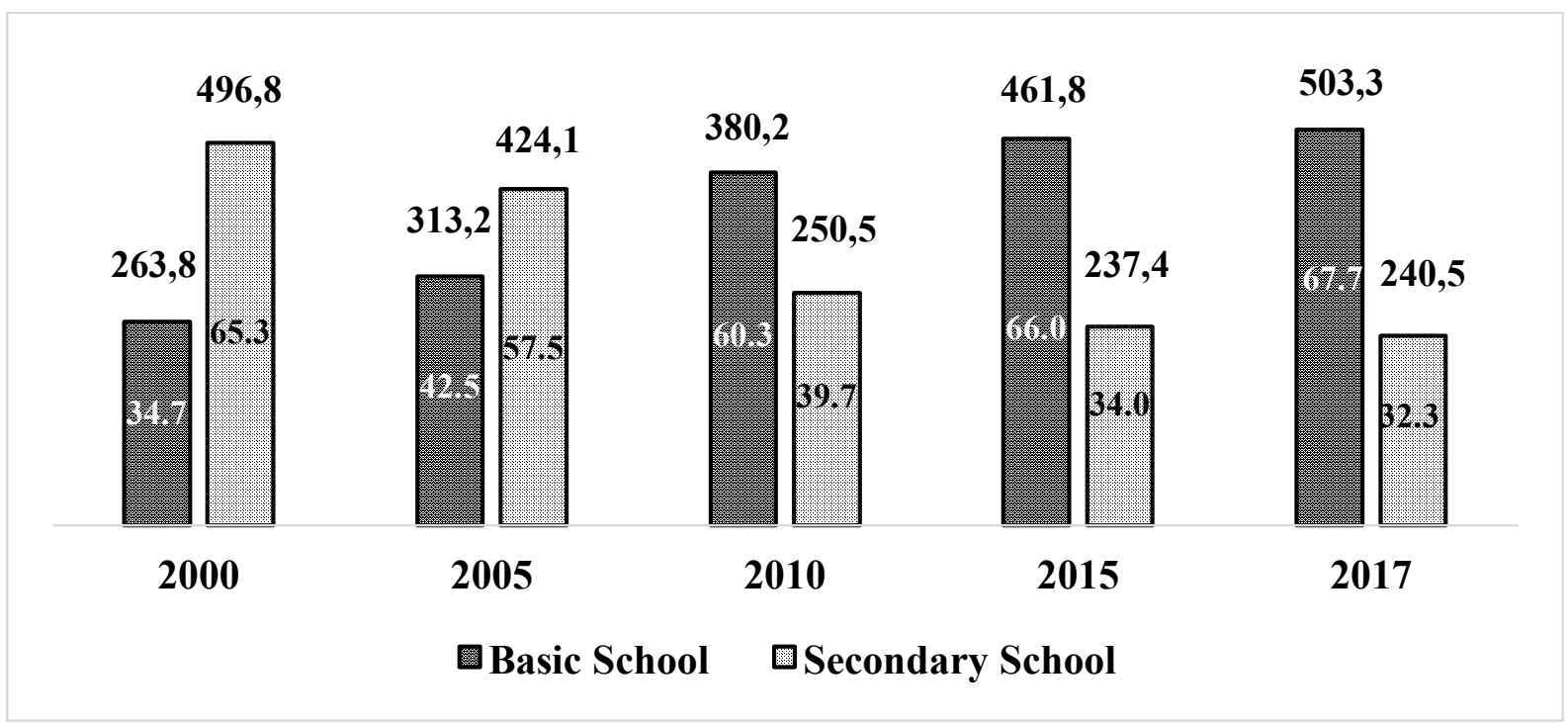

Figure 8. The number and proportions of Basic and Secondary Schools graduates in MLSP enrollment

Figure 9 illustrates changes in the educational attainment of MLSP enrollees. In 2000-2017, the proportion of enrollees with Basic Education was increasing fast (it more than doubled), and rates of growth were much higher among previous years' than among current-year graduates (resulting in a more than 7 -fold and 1.9-fold increase respectively). This means that MLSP training becomes more attractive not only to fresh Basic School graduates, but also to those who initialy entered the labour market but realized the need for vocational training later. 
Dynamics of the proportion of enrollees with Secondary Education is different. With the overall two-fold decrease, the proportion of enrolled current-year graduates fell more (by 2.7 times) than the proportion of previous years' graduates (by 1.4 times). The increasing competitive advantages of Secondary School current-year graduates in entering HEIs (see below) make the prospect of enrolling in MLSP less attractive to them whereas some of those graduates who failed to enter universities upon graduation enroll in MLSP later.

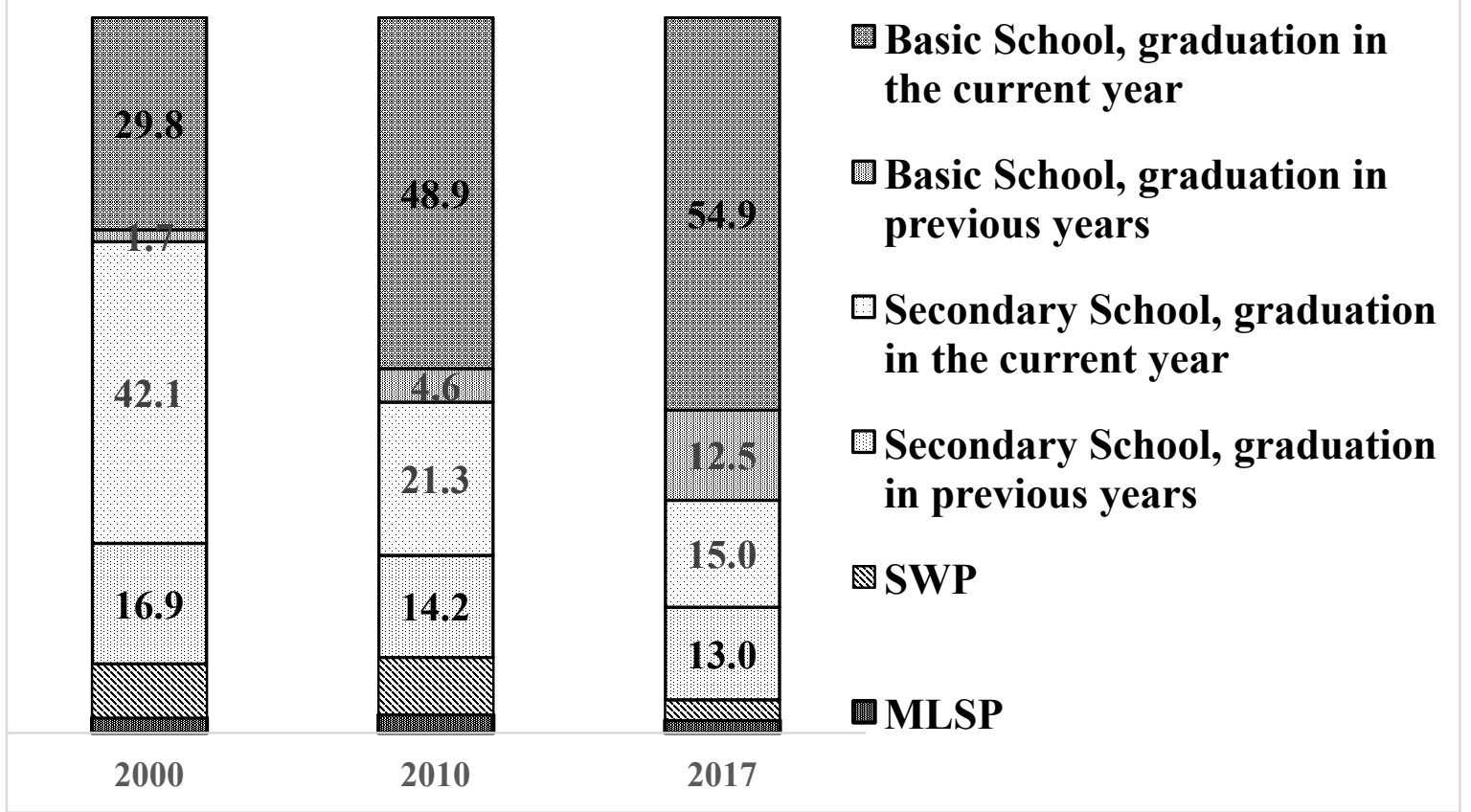

Figure 9. Levels of education among students enrolled in MLSP (\%)

The decreasing youth cohort and the increasing popularity of MLSP training among certain youth groups led to a broader coverage of youth with MLSP training in the reviewed period. The estmiated proportion of MLSP students among persons born 15-19 years before constituted 20.0\% in 2000, 28.2\% in 2010, and 36.5\% in 2017 (Obrazovanie 2014, 314; Goskomstat 2001, 133; Rosstat 2015, 37).

\section{Higher Education}

Higher Education is most attractive to youth, especially to Secondary School graduates. In 2000, when they could apply to only one HEI, competition for admission constituted an average of 1.9 persons per seat: 2.2 persons for full-time and 1.5 persons for extramural studies. By 2010, the overall figure reached 2.9 persons per seat due to increased competition for admission to full-time departments (up to 4.8 persons) whereas competition for entry into extramural departments remained the same. Competition for admission to public educational institutions was higher (5.1 and 1.6 persons for full-time and extramural studies respectively) than to private HEIs (1.8 and 1.2 persons respectively). A comparison with the current indicators is impossible since now graduates may apply to five HEIs simultaneously. The 2017 data are presented in Table 2 .

Competition for admission to bachelor's and specialist's degree progrfammes is much higher at public than at private institutions. The difference is even greater when comparing the largest groups of applicants. At public institutions, most of them apply for full-time studies $(62.9 \%$ of enrollment or $56.1 \%$ of overall HEI enrollment) where competition is 6.93 applications per seat (8.39 applications - per state-funded seat). At private institutions, most graduates apply for extramural studies (67.1\% of enrollees, or 7.3\% of overall HEI enrollment). Competition 
among them is 1.26 persons per seat, which means practically free access. At public institutions, competition for extramural studies is also low, and a considerable part of enrollees - 34.3\% - will obtain extramural education. Thus, four out of ten HEI enrollees get there through low competition.

Table 2.

Competition for admission to HEIs by mode of study in 2017: average number of applications per seat

\begin{tabular}{lcc}
\hline & Public HEIs & Private HEIs \\
\hline Full-time & 6.93 & 2.85 \\
Evening courses & 3.12 & 1.48 \\
Extramural & 2.26 & 1.26 \\
Total by Public HEIs and Private HEIs & 5.23 & 1.62 \\
Total by all HEIs & & 4.83 \\
\hline
\end{tabular}

Demand for employees with Higher Education in the labour market makes it desirable for youth. In 2000-2005, admission to HEIs increased against the background of the increasing age cohort. The conventional 18-year-old cohort (18 years is the modal value in the age distribution of HEI applicants) was up 7.3\% whereas the number of enrollees rose by $27.9 \%$ (Figure 10). The 2005-2010 period witnessed a sharp 44.9\% decline in the number of 18-yearolds (while enrollment was down by $26.4 \%$ ). The response was a gradual reduction in full-time enrollment. Meanwhile, extramural enrollment continued to increase until 2008, since three quarters of students are enrolled in self-paying seats even at public HEIs. Total admission to HEIs reached its maximum $(1,681,600$ persons $)$ in 2007.

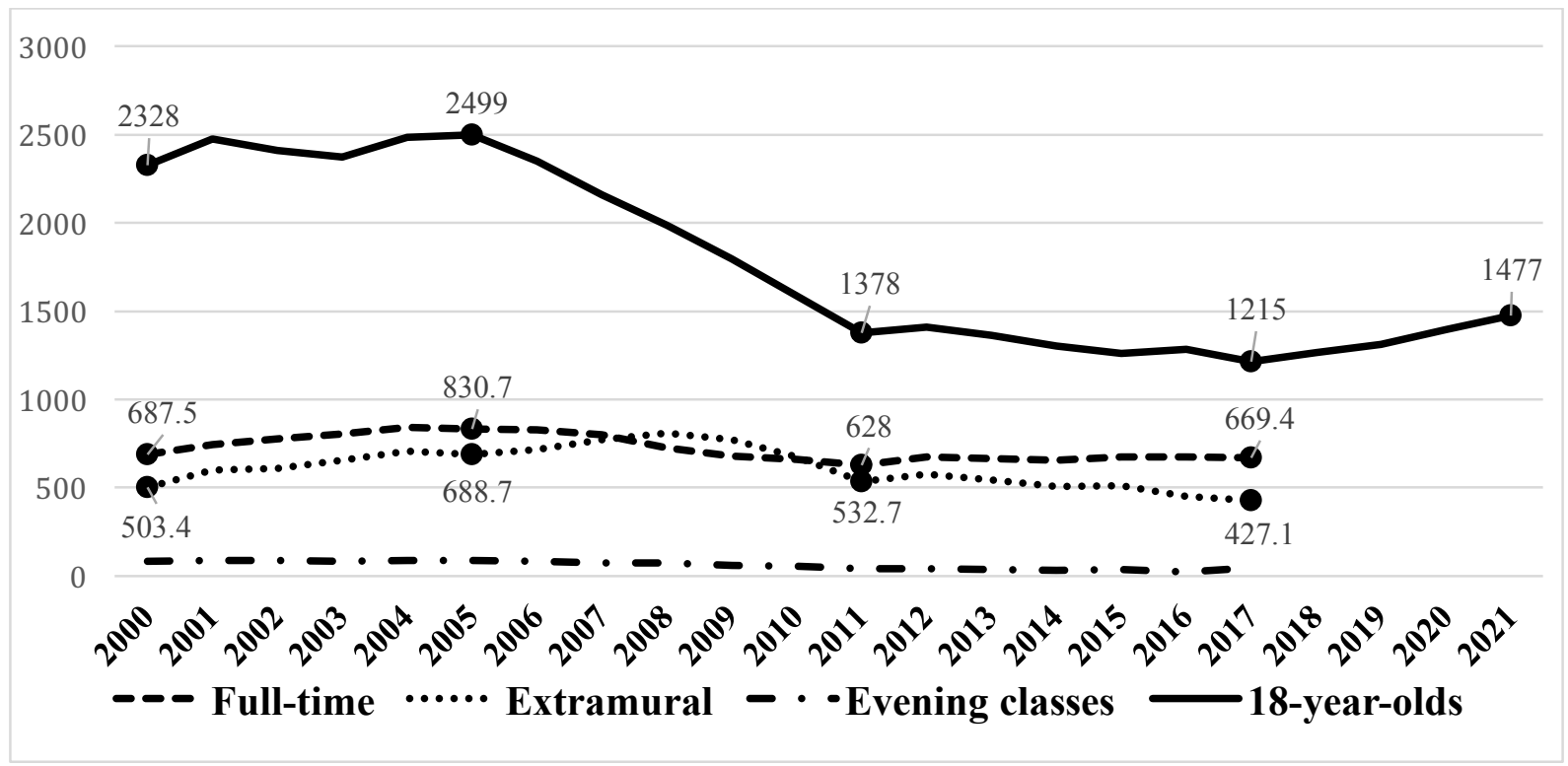

Figure 10. HEI's enrollment across modes of study, $(1,000)$

In 2011-2017, the decrease in the conventional 18-year-old cohort was small (11.8\%) and, after reaching its minimum, it started to increase in 2018. In 2012-2017, full-time HEI enrollment was relatively stable, while extramural enrollment was gradually decreasing and fell by $19.8 \%$ in $2011-2017$. It was in that period that small in numbers age cohorts began to 
enroll in extramural studies - many enrollees were older at admission than full-time enrollees. Besides, lower enrollment was a result of managarial decisions in recent years.

The data on changes in peer cohorts and HEI enrollment show that HEI enrollment growth rates exceeded the growth rates of the age cohort when the peer population increased whereas enrollment decreased at a slower pace than the peer population in periods of decline in the number of 18-year-olds. Therefore, coverage of youth with Higher Education has increased considerably. The proportion of full-time enrollees among the conventional 18-year-old-cohort was $29.5 \%$ in 2000, icreased to 33.2\% in 2005 and reached $41.6 \%$ in 2010 and $55.1 \%$ in 2017. The structure of HEI enrollment across modes of study was changing considerably (Table 3 ). Since 2000, full-time enrollment was steadily decreasing while extramural enrollment was increasing until 2009, when the former reached its minimum and the latter reached its maximum. After 2009, the trend reversed, and full-time enrollment has been increasing whereas extramural enrollment has been decreasing to this day. Enrollment in the mixed (fulltime/extramural) mode of study has always been very small. Evening classes have lost any substantial meaning as compared to their considerable popularity in Soviet time. They have been replaced by part-time employment of full-time students.

Table 3

HEI's enrollment across modes of study, \%

\begin{tabular}{lcccccc}
\hline & 2000 & 2005 & 2009 & 2010 & 2015 & 2017 \\
\hline Full-time & 53.2 & 50.1 & 43.9 & 47.1 & 55.3 & 59.1 \\
Extramural & 38.9 & 42.0 & 50.1 & 48.0 & 41.7 & 37.7 \\
Evening courses & 6.3 & 5.2 & 3.8 & 3.7 & 3.0 & 4.0 \\
External studies & 1.5 & 2.1 & 2.2 & 1.1 & - & - \\
Total & 100 & 100 & 100 & 100 & 100 & 100 \\
\hline
\end{tabular}

Full-time and extramural students differ considerably in their educational attainment at admission (Figure 11). The distribution of full-time enrollees across educational attainment levels has remained stable for many years: almost nine out of ten have Secondary Education obtained predominantly in the current years. The predominance of current-year graduates over those of previous years was the highest in conditions of low competition: $91.2 \%$ vs. $8.8 \%$ in 2011. By 2017, their proportions reached $83.5 \%$ and $13.4 \%$ respectively. Few enrollees have other kinds of education at admission, only the share of students with MLSP training is relatively noticeable. Therefore, competition for full-time HEI seats is predominantly in favor of current-year Secondary School graduates. 


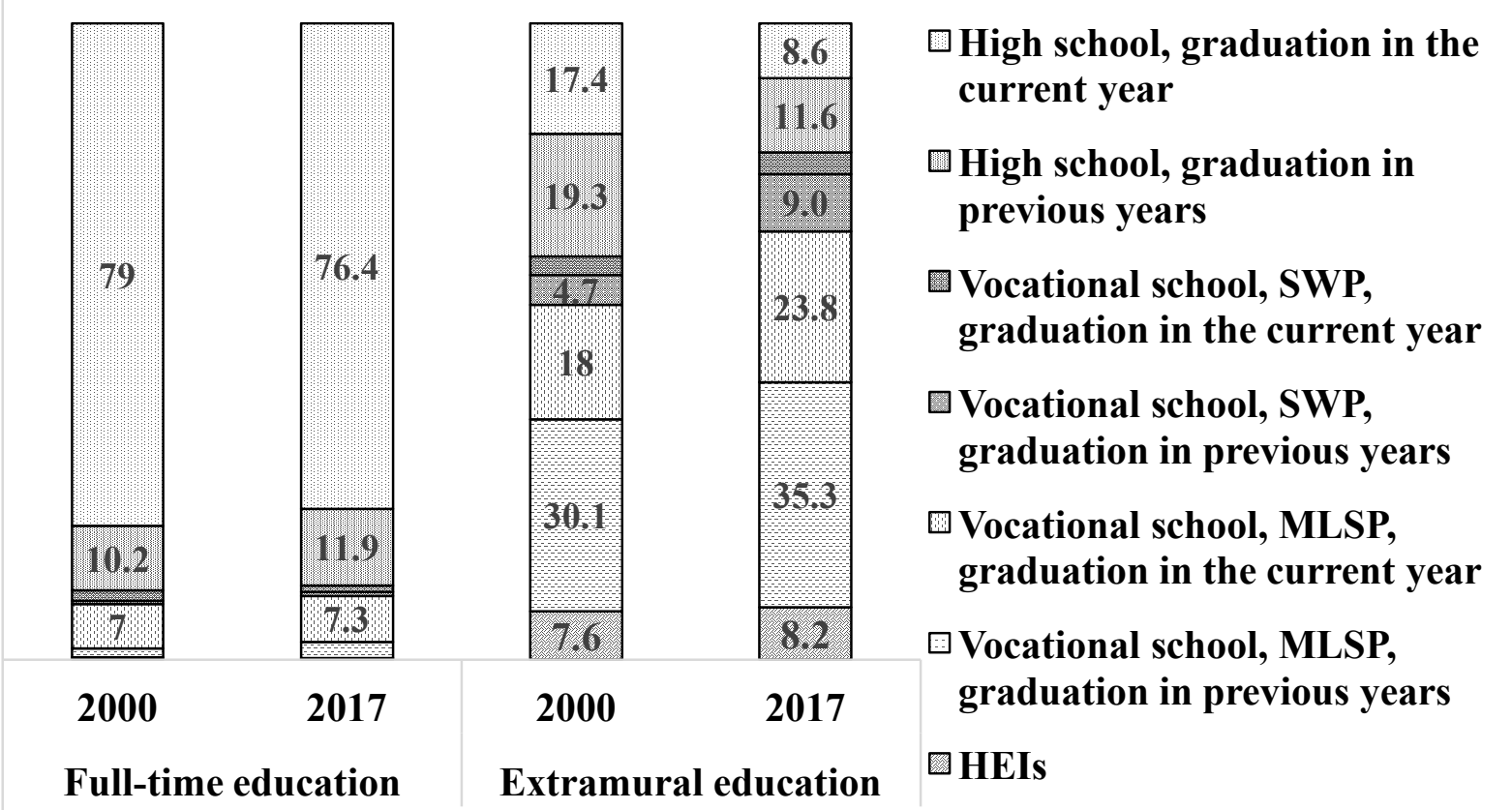

Figure 11. Levels of education among students enrolled in Full-time and Extramural studies, \% each year

Extramural enrollees have quite different educational attaintment at admission correlating with their wider age composition. Besides, educational attainment at admission has varied considerably. Extramural studies are much less popular among Secondary School graduates than full-time studies, and their popularity was considerably decreasing in the reviewed period. Moreover, previous years' graduates who failed (or did not try) to enter HEIs immediately upon graduation prevail among enrollees with Secondary Education. Extramural studies attract mostly students with MLSP training, and the share of current-year graduates is increasing. Young people with MLSP training who enter the labour market find out that their status is inferior to that of emloyees with Higher Education yet simultaneously opens career opportunities thanks to part-time education. Therefore, persons with MLSP training, mostly those employed, resort to extramural studies. A second Higher Education becomes increasingly popular today. According to law, it can be obtained only through extramural studies. The proportion of extramural enrollees with SWP training, i.e. with a worker's status, is slightly increasing.

A substantial advancement of Higher Education in the reviewed period is largely explained by a considerable expansion of paid educational services. They are provided by private HEIs and self-paing seats at public HEIs. Enrollment in private HEIs was increasing until 2007, and since then it has been decreasing under the impact of the demographic factor to this day: its proportion in total enrollment constituted 11.8\% in 2000, 17.7\% in 2007 and 14.6\% in 2017. The proportion of self-paying seats at public HEIs has been steadily increasing and constituted $42.8 \%, 48.3 \%$ and $50 . \%$ of total enrollment respectively. If summed up, these indicators show that $54.6 \%$ and $64.8 \%$ of youth enrolled in self-paying seats in 2000 and 2017 respectively (Obrazovanie 2012, 330; Obrazovanie 2014, 355, 363).

Extramural and full-time studies differ considerably in their possibilities of offering statefunded and paid education. Figure 12 illustrates the distribution of the 2017 enrollment across these modes of study. 


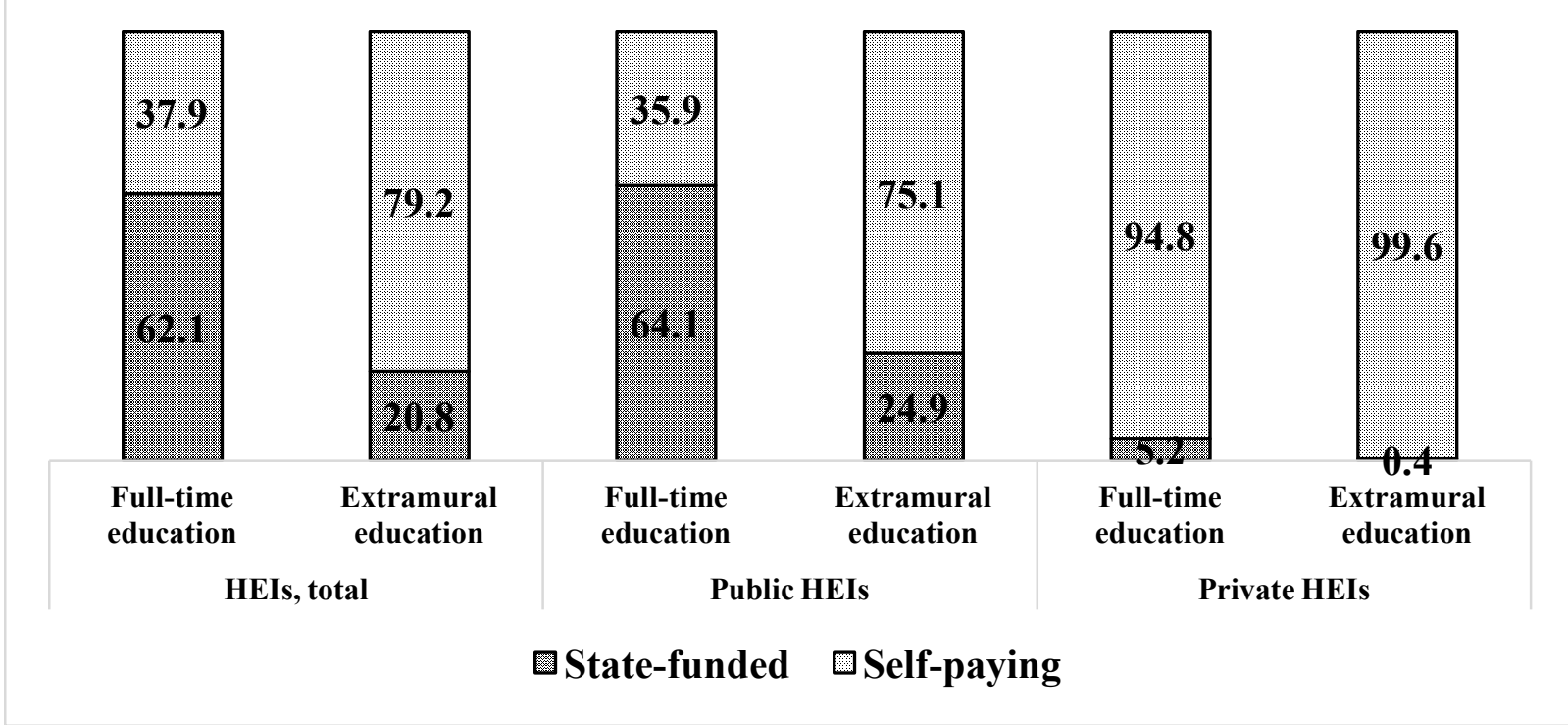

Figure 12. HEI enrollment in 2017 by forms of ownership and sources of funding

At public HEIs, full-time enrollees generally obtain state-funded education whereas extramural enrollees mostly pay a tuition fee. Private HEIs offer paid services on a practically universal basis. The sum total of these indicators and the fact that enrollment in public HEIs is 8.6 times higher than that in private HEIs show the following distribution of the overall number of enrollees across state-funded and self-paying seats: six out of ten full-time enrollees obtain state-funded seats, and eight out of ten extramural enrollees pay for their education. This is the most important general characteristic of full-time and extramural HEI enrollment.

\section{DISCUSSION}

It was quite recently that Russian researchers find that the distribution of youth after graduating from Basic School turns this institutional phase into the most important one influencing all subsequent trajectories of youth. This bifurcation plays a more substantial role than the "Secondary School to HEI" track in producing social inequality (Bessudnov A., Malik V., 2016). The sociological studies confirm that the "Basic School to MLSP to HEI" track has become popular in the past decade, especially among social groups with limited cultural and material resources. Some researchers emphasize that such is the social role played by SVE, which is no less substantial than its instrumental mission (Konstantinovsky D., Popova E., 2018, 41). Others maintain that the current MLSP turns into a mobility channel for disadvantaged youth (Alexandrov D. et al. 2015). Many authors tend to base their arguments on the analysis of the current shortcomings of Higher Education and ways of overcoming them by a joint review of the state of affairs in both education systems.

These numerous studies and public discussions us information on educational tracks and attained levels of education of young people to raise on the front burner issues: increasing mismatch between the actual labor market demand for both skills mix and their number (largely attributed to various irregularities of development of the Secondary Vocational and Higher Education systems), stratification within the Higher Education system and differentiation of certificates in the labor market including devaluation of some of them (Zubok Y.A., Chuprov 2015; Kliucharev 2015; Konstantinovsky, Popova 2015). As well as the issues of a heterogeneous and highly diversified Higher Education structure, with the result that institutions (and their structural units) could be categorized by the quality of provided education into "leaders", "a second line", and "outsiders". (Klyachko 2002). 
A most critically-minded scholar writes that overgrowth of these second and especially third segments of Higher Education results from an artificial increase in skills supply, which undermines healthy competition and distracts millions of people from productive activities in the real economy (Inozemtsev 2016). The rigorous socioeconomic study shows that the number and the quality of training programs of Higher Education does not fit into the Russian economic structure; many graduates are employed in jobs other than their specialties or/and in jobs intended for mid-level specialists with Secondary Vocational Education whom the labor market requires (Klyachko 2016, Navyki 2018). Serious attempts are made at describing important measures that should be taken to reform Secondary Vocational Education to bring its nearer to MLSP and SWP systems in industrialized countries (Belyakov et al. 2018).

When the State has ceased to be the key requester of university-trained skills and attention has focused on demand from specific labor market segments, the agenda of educational reforms has changed. Universities need to contribute actively to the economy and society and, therefore, optimization of Higher Education must be aimed at creating a viable HEI diversity permitting to meet society's needs. (Kuzminov et al. 2013).

\section{CONCLUSION}

Educational trajectories pursued by young people, who move from level to level in the education system, and opportunities for mobility within the system are contingent on a complex web of many interdependent factors. The latter include the structure and institutionalization of the education system, educational needs, and the selectiveness of young people. These factors shift all the time, depending heavily on the economic and social demand for human resources of specific qualifications and majors as well as on the existing vector of technology and social development. Both the education system and the labor market must undergo a transformation to solve disagreements that inevitably arise between them. For instance, devaluation of college education and the sector of low-quality colleges cannot be fought successively in a situation where only one part of the labor market seeks highlyqualified professionals, while the other, mostly represented by service agencies and small and medium-sized businesses, is well-contented with a diploma's social function of indicating that a college graduate has acquired a set of social and cultural competencies. The situation will only change when the secondary. and the tertiary sectors actually express a demand for high quality of youth education and most structural elements of the economic system actually focus on intensification, modernization and innovations in their development. On the other hand, the system of Vocational Education (MLSP) will keep playing the role of an educational bridge until it upgrades the program content essentially and begins teaching the universal competencies of a mid-level specialist in addition to technical specialization. Special, including statistic, studies concerning the educational trajectories of youth and their correlation with the paths young people take when entering the labor market contribute, to the best of their ability, to keeping stakeholders informed on the subject.

\section{References}

Alexandrov, D., Tenisheva, K., Savelieva, S. 2015. "Mobilnost bez riskov: obrazovatelnyy put "v universitet cherez kolledzh" [Risk-free mobility: an educational path "To University through College-MLSP"]. Voprosy obrazovaniya /Educational Studies Moscow], no 3. (In Russ.).

Belyakov, S., Klyachko, T., Polushkina, E. 2018. Srednee professionalnoe obrazovanie: sostoyanie i prognoz razvitiya [Secondary vocational education: state and forecast of development]. Moscow: Publishing house "Delo", RANEPA. (In Russ.). 
Bessudnov, A., Malik, V. 2016. Soczial`no-e`konomicheskoe i gendernoe neravenstvo pri vy`bore obrazovatel`noj traektorii posle okonchaniya 9 go klassa srednej shkoly` [Socioeconomic and gender inequality in the choice of educational trajectory after the graduation from the 9th grade of secondary school]. Voprosy obrazovaniya [Educational Studies Moscow], no 1. (In Russ.).

Boslaugh, Sarah. 2013. Statistics in a Nutshell. 2nd Edition. O'Reilly Media, Inc.

Goskomstat. 2001. Demograficheskiy yezhegodnik Rossii 2001. Stat. sb. [Demographic Yearbook of Russia 2001. Statistical Book. Moscow: Goskomstat. (In Russ.)

Education at a Glance 2017. https://www.hm.ee/sites/default/files/eag2017_eng.pdf

Indikatoryi obrazovaniya. 2018. Statisticheskiy sbornik [Education Indicators 2018. Statistical collection]. Moscow: NRU HSE. (In Russ.)

Inozemtsev, V. 2016. Zlokachestvennoe vyisshee obrazovanie. [Malignant Higher Education]. Snob. (February) https://snob.ru/selected/entry/111790. (In Russ.)

Kliucharev, G. 2015. «Razry`v» obrazovaniya i ry`nka truda: mneniya e`kspertov [The "gap" in education and the labor market: the views of experts] Sotsiologicheskie issledovaniya [Sociological studies], no. 11. (In Russ.)

Klyachko, T. (ed.). 2002. Modernizatsiya rossiyskogo obrazovaniya: resursny potentsial i podgotovka kadrov [Upgrading of Russian Education: Resource Potential and Personnel Training]. Moscow: HSE. (In Russ.)

Klyachko, T. 2016. "Vyisshee obrazovanie: bolshe, luchshe ili deshevle?" [Higher education: more, better or cheaper?] Demoskop Weekly, no 669-760 http://www.demoscope.ru/weekly/2016/0669/index.php (In Russ.)

Konstantinovsky, D., Popova, E. 2015. "Molodezh, ryinok truda i ekspansiya vyisshego obrazovaniya” [Youth, labor market and expansion of higher education]. Sotsiologicheskie issledovaniya [Sociological studies], no 11. (In Russ.)

Konstantinovskiy, D., Popova, E. 2018 "Rossiyskoe srednee professionalnoe obrazovanie: vostrebovannost i spetsifika vyibora" [Russian secondary vocational education: demand and specificity of choice] Sotsiologicheskie issledovaniya. [Sociological studies], no 3. (In Russ.)

Kuzminov, Ya., Semenov, D., Frumin, I. 2013. "Struktura vuzovskoy seti: ot sovetskogo k rossiyskomu «masterplanu»" [The structure of the university network: from the Soviet to the Russian "master plan"] Voprosy obrazovaniya [Educational Studies Moscow], no 4. (In Russ.).

Ministerstvo obrazovaniya i nauki Rossiyskoy Federatsii [The Ministry of Education and Science of the Russian Federation]: http:// минобрнауки.рф/министерство/статистика. (In Russ.)

"Navyiki i kompetentsii, priobretaemyie studentami vo vremya obucheniya v vuze: sootvetstvie potrebnostyam ryinka truda" 2018. [The skills and competences acquired by students during training in higher education institution: compliance to requirements of labor market]. Monitoring of Education, Markets and Organizations. Moscow: NRU HSE. Is. 13. (In Russ.)

Obrazovanie v Rossiyskoy Federatsii. 2012. Statisticheskiy sbornik [Education in the Russian Federation 2012. Statistical Book]. Moscow: NRU HSE. (In Russ.)

Obrazovanie v Rossiyskoy Federatsii 2014. Statisticheskiy sbornik [Education in the Russian Federation 2014. Statistical Book]. Moscow: NRU HSE. (In Russ.)

Obrazovanie v tsifrah 2018. Statisticheskiy sbornik [Education in numbers 2018. Statistical collection]. Moscow: NRU HSE. (In Russ.)

Primary statistics data of education for 2000-2010 that the Federal State Statistics Service officially provided to the Department of Sociology of Education of the Institute of Sociology of the Russian Academy of Sciences (data array in Russ.)

Rossiyskaya sistema obrazovaniya v formate Mezhdunarodnoy standartnoy klassifikatsiey obrazovaniya MSKO 2011. 2016. [Russian education system in the format of the International Standard Classification of Education (ISCED) 2011]. Moscow: FGBU Glavexperttsentr. (In Russ.)

Rosstat. 2015. Demograficheskiy yezhegodnik Rossii 2015. Stat. sb. [Demographic Yearbook of Russia 2001. Statistical Book], Moscow: Rosstat. (In Russ.)

"Srednee professionalnoe obrazovanie: sostoyanie i vyizovyi" 2016 [Secondary vocational education: status and challenges]. Monitoring ekonomiki obrazovaniya. Informatsionno-analiticheskie materialyi po rezultatam sotsiologicheskih obsledovaniy [Monitoring of Education Markets and Organizations. Information and analytical materials on the results of sociological surveys]. Moscow: NRU HSE. Is. 26. (In Russ.)

The World Bank. Education Statistics. https://datacatalog.worldbank.org/dataset/education-statistics 
Galina, C. (2019). Educational Tracks Of Russian Youth In System Of Education (On State Statistics 2000-2017). Advances in Social Sciences Research Journal, 6(3) 366-382.

Zubok, Y., Chuprov, V. 2015. Molody`e speczialisty`: problema podgotovki i polozhenie na ry`nke truda [Young specialists: the problem of training and position on the labor market] Sotsiologicheskie issledovaniya [Sociological studies], no: 5. (In Russ.) 